\title{
IMPACT OF AGRICULTURE DRAINAGE CONDITIONS ON WATERTABLE RECESSION AND SOME CLAY SOIL
} PROPERTIES, NILE DELTA.

Abdel-Mawgoud, A. S. A. ${ }^{1}$, M.A. B. El-Sheikh ${ }^{2}$ and M.I.I. AbdelKhalik ${ }^{2}$

1- Soils \& Water Dept., Fac. of Agric., Al-Azhar Univ., Assiut, Egypt.

2- Soils, Water \& Env. Res. Inst., Agric. Res. Centre, Giza, Egypt.

\section{ABSTRACT}

An experimental field was constructed on a heavy clay soil at the northeast Delta (Dakhlia Governorate) to study the effect of different tile drain spacings on watertable recession and some physical and chemical properties of heavy clay soil. The experimental field was provided by tile drainage system with three drain spacing treatments $(15,30$ and $60 \mathrm{~m})$ at fixed depth of $1.5 \mathrm{~m}$.

The results indicated that by the end of the irrigation interval (after three weeks), the watertable level went deeper to reach 131, 103 and $94 \mathrm{~cm}$ soil depth for 15,30 and 60 $\mathrm{m}$ tile drain spacing treatment, respectively. The average watertable drawdown rate through an irrigation interval was $6.24,4.90$ and $4.48 \mathrm{~cm} /$ day for the corresponding treatments. The watertable drawdown ratio $\left(\mathrm{h}_{\mathrm{t}} / \mathrm{H}_{\mathrm{o}}\right)$ decreased as the tile drain spacing became wider. It was $0.87,0.69$ and 0.63 after three week for the corresponding treatments. The soil moisture content increased as tile drain spacing increased. It increased by 16 and $26 \%$ in surface layer and by 18 and $30 \%$ in subsurface layer under 30 and $60 \mathrm{~m}$ tile drain spacing, respectively compared to the narrow one. Soil bulk density increased as tile drain spacing increased. It increased by 4 and $11 \%$ in surface layer and by 3 and $9 \%$ in subsurface layer under 30 and $60 \mathrm{~m}$ tile drain spacing, respectively compared to the narrow one. Total soil porosity decreased as tile drain spacing increased. It decreased by 3 and $9 \%$ in surface layer and by 3 and $8 \%$ in subsurface layer under 30 and $60 \mathrm{~m}$ tile drain spacing, respectively compared to the narrow one. Tile drain spacing treatments realized a postive effect on soil salinity. The reduction in soil salinity followed the order of: 15>30>60 m tile drain spacing. The soil salinity was reduced by 13 and $41 \%$ in surface layer and by 26 and $39 \%$ in the subsurface layer under 30 and $60 \mathrm{~m}$ tile drain spacing, respectively compared to the narrow one. The reduction in soil sodicity followed the order of: 15> $30>60 \mathrm{~m}$ tile drain spacing. The soil sodicity reduced by 13 and $46 \%$ in surface layer and by 24 and $46 \%$ in the subsurface layer under 30 and $60 \mathrm{~m}$ tile drain spacing, respectively compared to the narrow one.

Tile drain spacing treatments realized an enhancing effect which progressively as time proceeded by lowering the water table and accelerated its recession, particularly under narrow spacing traetment. However, treatment of $30 \mathrm{~m}$ drain spacing gave satisfactory results by lowering watertable and reducing salinity and alkalinity with improving soil physical properties. It is also reduce drainage costs. Also, tile drainage spacing treatments promoted a favourable conditions by decreasing soil salinity and sodicity and creating a suitable soil moisture content which plays an important role in improving soil moisture-aeration status in the root zone.

Keywords: Clay Soil, Tile Drain Spacing, Watertable Recession, Bulk Density, Total Porosity

\section{INTRODUCTION}

Clay soils underlain by shallow saline ground water in the northern part of the Nile Delta are subjected to severe salinity problems. The flucatuation of water 
table depth affects soil properties and crop productivity. The shallow water table reduces plant growth due to decrease rooting volume and insufficient oxygen. Artificial drainage becomes necessary to control water table variability and to maintain a suitable aerated zone (Moukhtar and El-Hakim, 2004).

Wenberg (1990) reported that subsurface drainage must be adequate to permit the necessary leaching, hold the ground watertable to sufficient depth and prevent the upward movement of salty capillary water to reach into root zone. Many investigators such as Semedma \& Rycroft (1983), Ritzema (1994) and Moukhtar et al. (1995 \& 1996) mentioned that heavy clay soils of low permeablity often require very close drain space for satisfactory water control in order to sustain agriculture production. Rao et al. (1995) pointed out that drain spacing of 65 to $75 \mathrm{~m}$ with drain depth of 1.40 to $1.75 \mathrm{~m}$ for semi-arid parts and drain spacing as wide as $100 \mathrm{~m}$ with a depth of $1.75 \mathrm{~m}$ for the arid parts can provide sufficient drainage.

Abd-Allah (2000) stated that decreased the distance between tile drains led to accelerate the draw down rate of water table which enhance the aeration and improve soil sturcture. Ragab (2000) stated that soil salinity decreased in drained soils with different dgrees depending on drain spacing and depth. Faltas and Naguib (2001) indicated that the salt leaching took place steadily and significantly under 20 and $40 \mathrm{~m}$ drain spacings. While for the $80 \mathrm{~m}$ spacing, there was insignificant decrease in salt content. El-Hadidy et al. (2003) stated that an improvement in drainage conditions is realized progressively as time proceeds, especially under narrow spacing. They also, found that water table draw down rate depends on the distance of drain spacing. Wasef (2004) found that enhanced soil hydraulic properties by lowering water table level was more effective under closed drain spacing that that of wide one. Mohamedin and El-Sawaf (2005) found that the total soil porosity increased by 2.8, 4.1 and $5.1 \%$ for tile drain spacing of 40,30 and 20 m., respectively.

The present work has been set up to study the effect of different tile drain spacings on watertable recession and some physical and chemical properties of heavy clay soil.

\section{MATERIALS AND METHODS}

An experimental field was constructed on a heavy clay soil at the northeast Delta (Dakhlia Governorate). The physical and chemical properties of the studied area are shown in Table (1). The experimental field was provided by tile drainage system and it was designed with three drain spacing treatments separated by buffer zones according to Dielman and Trafford (1976) at fixed depth of $1.5 \mathrm{~m}$. The drain spacing treatments were $15 \mathrm{~m}$. as calculated on steady state formula according to Houghoudt (1940)(same equation still used by National Drainage Project), $30 \mathrm{~m}$. spacing (conventional spacing adopted in the surrounding areas) and $60 \mathrm{~m}$. spacing (double of the conventional spacing adopted in the surrounding areas).

Disturbed soil samples (from $0-30$ and $30-60 \mathrm{~cm}$ depth) were collected from each treatment, then air-dried, ground to pass a $2 \mathrm{~mm}$ sieve 
and subjected for chemical analysis according to Page et al. (1982). Also, undisturbed soil samples were taken from the same soil depth using cores with $4.3 \mathrm{~cm}$ diameter and $3.0 \mathrm{~cm}$ height to determine soil moisture content, bulk density and total porosity according to the procedure outlined by Klute (1986). The soil moisture content was determined at the midway between the tile drains one week after irrigation.

Water table recession was measured through observation wells (19 $\mathrm{mm}$. Diameter and $2 \mathrm{~m}$. length) located at midway between tile drains in each treatment. Water table depth was measured by a sounder consisting of a $1.25 \mathrm{~cm}$ diameter copper tube and $5.0 \mathrm{~cm}$ in length connected with a calibrated steel tape. Data were measured daily and directly after irrigation through an irrigation interval ( 21 days).

Table 1: (a) Some physical properties of the investigated soil.

\begin{tabular}{|c|c|c|c|c|c|c|c|c|}
\hline \multirow{2}{*}{\begin{tabular}{|l} 
Soil \\
depth \\
(cm)
\end{tabular}} & \multicolumn{3}{|c|}{ Particle size distribution } & \multirow{2}{*}{$\begin{array}{l}\text { Texture } \\
\text { class }\end{array}$} & \multirow{2}{*}{$\underset{\%}{O . M .}$} & \multirow{2}{*}{$\underset{\%}{\mathrm{CaCO}_{3}}$} & \multirow{2}{*}{$\begin{array}{c}\mathrm{Bd} \\
\left(\mathrm{Mg} \mathrm{m}^{-3}\right)\end{array}$} & \multirow{2}{*}{$\begin{array}{c}\text { Total } \\
\text { porosity\% }\end{array}$} \\
\hline & Sand \% & $\begin{array}{c}\text { Silt } \\
\%\end{array}$ & $\begin{array}{c}\text { Clay } \\
\%\end{array}$ & & & & & \\
\hline $0-30$ & 16.68 & 23.41 & 59.91 & Clay & 1.28 & 2.43 & 1.32 & 49.22 \\
\hline $30-60$ & 17.83 & 22.48 & 60.16 & Clay & 0.62 & 2.65 & 1.38 & 47.60 \\
\hline Mean & 17.26 & 22.94 & 59.80 & Clay & 0.95 & 2.54 & 1.35 & 48.41 \\
\hline
\end{tabular}

O.M.: organic matter

Bd: bulk density

(c) Some chemical properties of the investigated soil.

\begin{tabular}{|l|c|c|c|c|c|c|c|c|c|c|c|c|}
\hline $\begin{array}{l}\text { Soil } \\
\text { Depth } \\
(\mathbf{c m})\end{array}$ & $\mathbf{p H}$ & \multirow{2}{*}{$\begin{array}{c}\mathbf{E C} \\
\mathbf{( d S} / \mathbf{m})\end{array}$} & $\mathbf{C O}_{\mathbf{3}}$ & $\mathbf{H C O}_{\mathbf{3}}$ & $\mathbf{C l}$ & $\mathbf{S O}_{\mathbf{4}}$ & $\mathbf{C a}$ & $\mathbf{M g}$ & $\mathbf{N a}$ & $\mathbf{K}$ & SAR & ESP \\
\hline $\mathbf{0 - 3 0}$ & 8.15 & 5.89 & 0.0 & 3.74 & 51.39 & 6.66 & 5.42 & 2.35 & 52.25 & 1.77 & 26.51 & 20 \\
\hline $\mathbf{3 0 - 6 0}$ & 8.25 & 6.95 & 0.0 & 3.11 & 60.38 & 8.96 & 6.49 & 2.81 & 60.81 & 2.34 & 28.20 & 21 \\
\hline Mean & 8.20 & 6.42 & 0.0 & 3.43 & 55.89 & 7.81 & 5.96 & 2.58 & 56.53 & 2.06 & 27.36 & 21 \\
\hline
\end{tabular}

\section{RESULTS AND DISCUSSION}

Watertable recession: Watertable depth at midway between tile drains through an irrigation interval (21 days) for different tile drain spacings is shown in Fig. (1). In general, upon irrigation, watertable level raised rapidly close to soil surface and then receded gradually. After one week, the watertable level went to 89,64 and $62 \mathrm{~cm}$ soil depth for 15,30 and $60 \mathrm{~m}$ tile drain spacing treatment, respectively. After two week, the watertable level went to 116,81 and $79 \mathrm{~cm}$ soil depth for the coresponding tile drain spacing treatment. By the end of the irrigation interval (after three week), the watertable level went deeper to reach 131, 103 and $94 \mathrm{~cm}$ soil depth for the coresponding tile drain spacing treatment. The data indicted that the narrow tile drain spacing realized fast recession of watertable level through a certain period compared with that of wider tile drain spacing. Also, the watertable level went deeper under narrow tile drain spacing compared to the wider one. Similar results were obtained by Moukhtar et al. (1990a). 


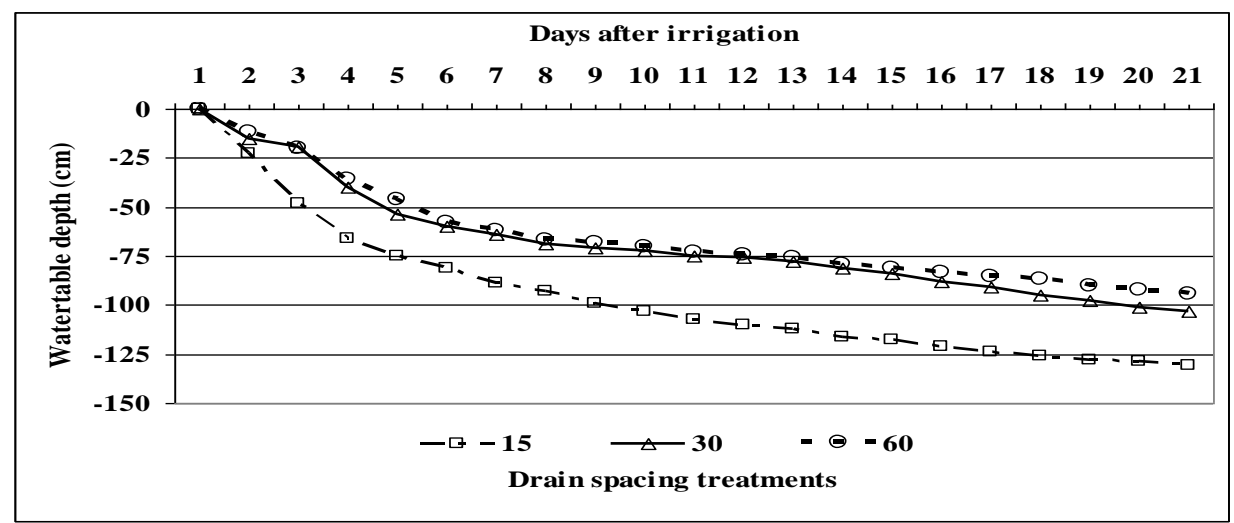

Fig. (1). Watertable depth midway between tile drains through an irrigation interval under different tile drain spacing.

The watertable drawdown rate in the first week, was 12.7, 9.1 and $8.7 \mathrm{~cm} /$ day for 15,30 and $60 \mathrm{~m}$ tile drain spacing treatment, respectively. The watertable drawdown rate was $3.9,2.4$ and $2.4 \mathrm{~cm} /$ day in the second week and it was 2.1, 2.7 and $2.1 \mathrm{~cm} /$ day in the thrid week for the coresponding tile drain spacing treatment. The average watertable drawdown rate through an irrigation interval was $6.2,4.9$ and $4.5 \mathrm{~cm} /$ day for 15,30 and $60 \mathrm{~m}$ tile drain spacing treatment, respectively. The obtained results revealed that the improving drainage condition by drying the soil was more evident under $15 \mathrm{~m}$ tile drain spacing and followed 30 then $60 \mathrm{~m}$ tile drain spacing. Similar results were obtained by Moukhtar et al. (1990b). The fluctuation of watertable level was highly affected by different tile drain spacing with time which could be expained by the following regration equations:

For $15 \mathrm{~m}$ tile drain spacing: $Y=-5.2416 X-37.533$

For $30 \mathrm{~m}$ tile drain spacing: $Y=-4.3078 X-20.90$

For $60 \mathrm{~m}$ tile drain spacing: $Y=-3.9844 X-20.60$

$\left(R^{2}=0.870\right)$

$\left(R^{2}=0.845\right)$

Watertable drawdown ratio: The impact of tile drain spacing treatments on drainage conditions improvement could be illustrated by the parameter of watertable drawdown ratio $\left(h_{t} / H_{0}\right)$ wher $h_{t}$ is the measured watertable at " $t$ " time and $H_{\circ}$ is equal to drain depth $(150 \mathrm{~cm})$. The parameter was calculated for different watertable position midway between tile drain spacing during irrigation interval of 21 days. In general, the obtained results indicated that an improvement in drainage condition was realized progressively as time proceeded especially under $15 \mathrm{~m}$ tile drain spacing treatment. Data presented in Fig. (2) showed that the watertable drawdown ratio $\left(h_{t} / H_{0}\right)$ decreased as the tile drain spacing became wider. The watertable drawdown ratio $\left(h_{t} / H_{0}\right)$ was $0.59,0.43$ and 0.41 for 15,30 and $60 \mathrm{~m}$ tile drain spacing treatment, respectively after one week. The estimated value was $0.77,0.54$ and 0.53 after two week and $0.87,0.69$ and 0.63 after three week for the coresponding treatments. It could be noticed that the vlues of $h_{t} / H_{0}$ were very close under both 30 and $60 \mathrm{~m}$ tile drain spacing treatments at a certain time. This mean that the narrow tile drain spacing $(15 \mathrm{~m})$ was more effective in 
reducing watertable level than the other treatment which could be explained by the regretion equation as followes:

For $15 \mathrm{~m}$ tile drain spacing: $Y=0.0304 X+0.3467$

For $30 \mathrm{~m}$ tile drain spacing: $Y=0.0261 X+0.2043$

For $60 \mathrm{~m}$ tile drain spacing: $Y=0.024 X+0.1993$

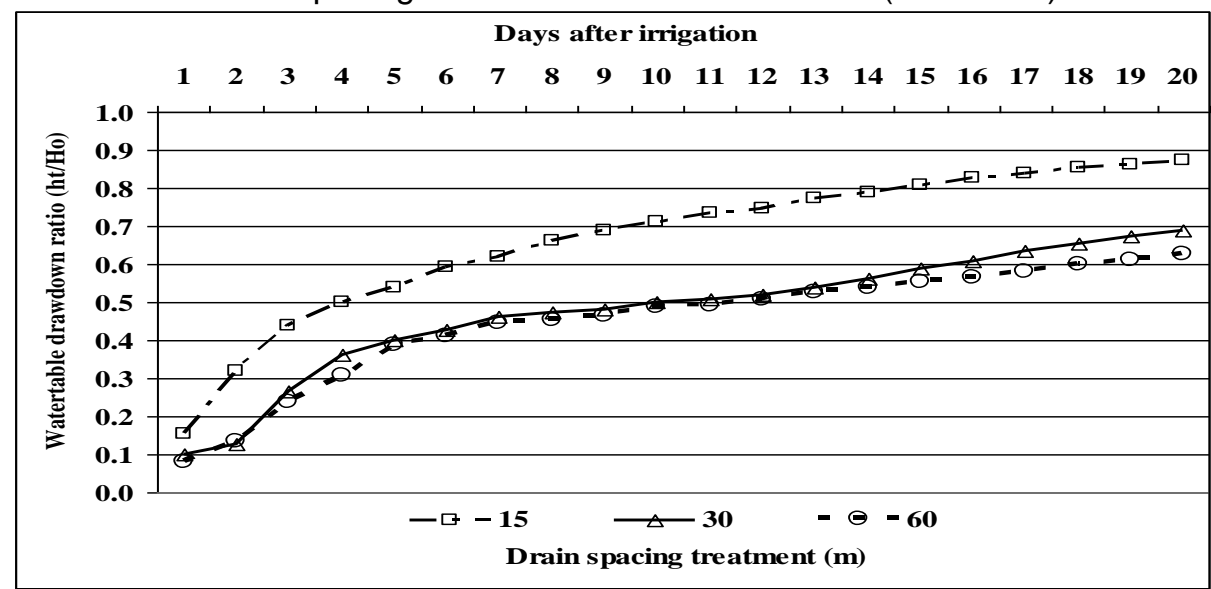

Fig. (2). Watertable drawdown ratio $\left(h_{t} / H_{0}\right)$ through an irrigation interval under different tile drain spacing.

Data in Fig. (3) showed the effect of tile drain spacing treatments on soil moisture content percentage in surface and subsurface layers. In general, the data indicated that the soil moisture content in the surface layer was less than that of subsurface layer under all tile drain spacing treatments. Also, the data revealed that the soil moisture conten increased as tile drain spacing increased.

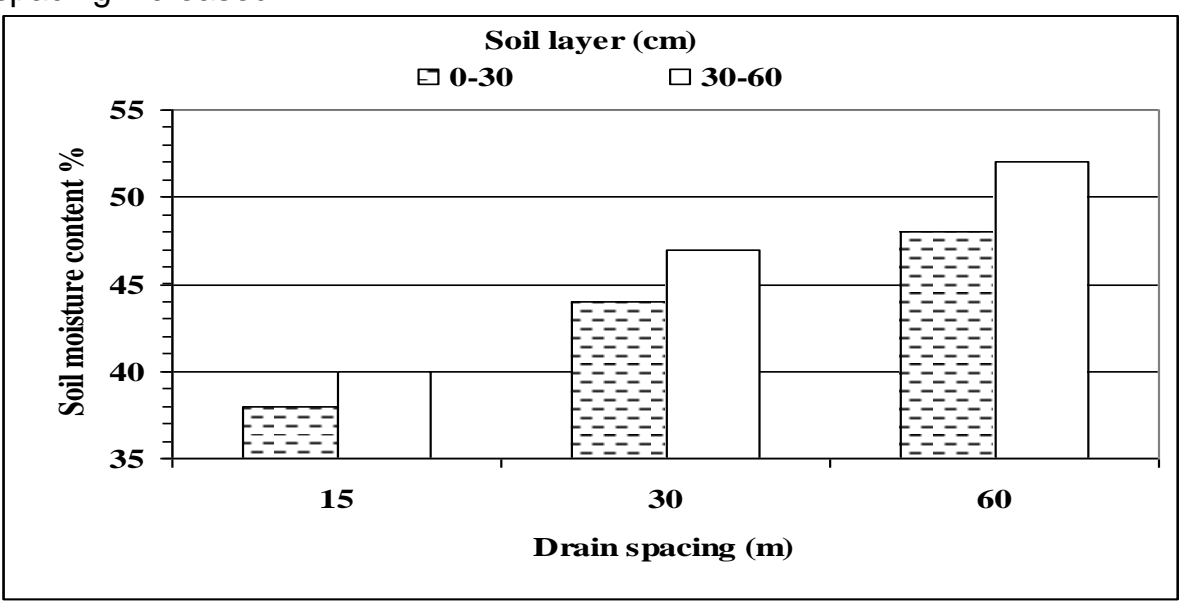

Fig. (3). Soil moisture content percentage midway between tile drains after one week from irrigation in surface and subsurface layers as affected by tile drain spacing treatments. 
The soil moistur content increased by 15.8 and $26.3 \%$ in surface layer and it increase by 17.5 and $30.0 \%$ in subsurface layer under 30 and $60 \mathrm{~m}$ tile drain spacing, respectively compared to the norrw one.

Data in Fig. (4) showed the effect of tile drain spacing treatments on soil bulk density in surface and subsurface layers. In general, the data indicated that soil bulk density increased with soil depth. Also, soil bulk density increased as tile drain spacing increased. It increased by 4.3 and $11.2 \%$ in surface layer and it increase by 3.2 and $8.9 \%$ in subsurface layer under 30 and $60 \mathrm{~m}$ tile drain spacing, respectively compared to the norrw one.

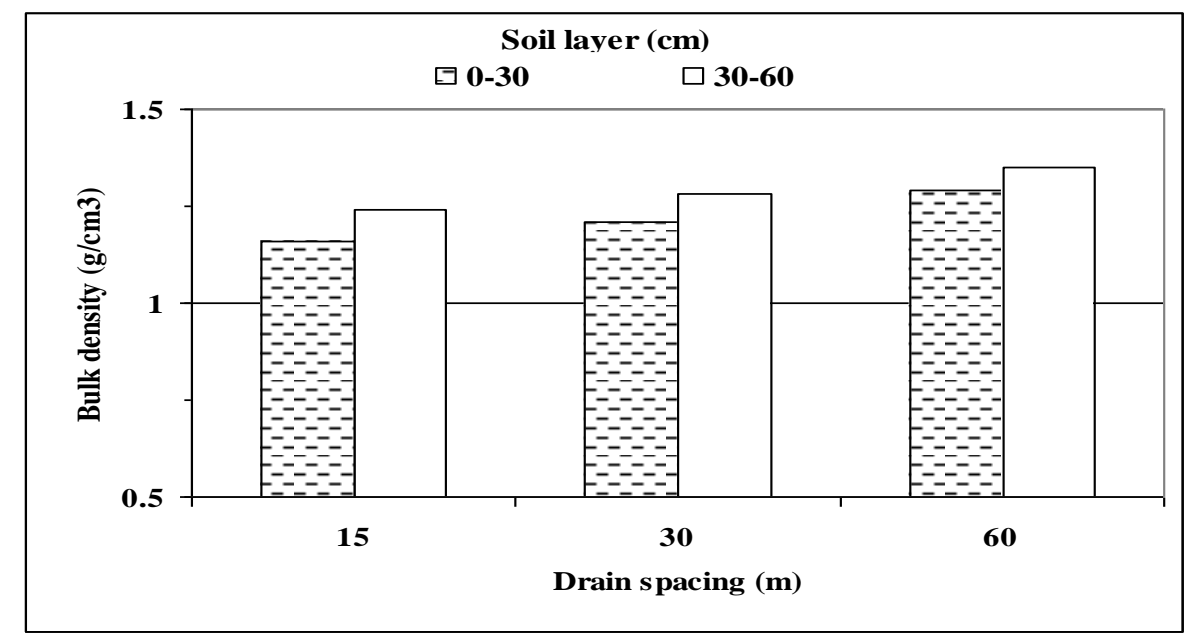

Fig. (4). Soil bulk density $\left(\mathrm{g} / \mathrm{cm}^{3}\right)$ in surface and subsurface layers as affected by tile drain spacing treatments.

In general, the data presented in Fig. (5) indicated that total soil porosity decresed with soil depth. Also it decreased as tile drain spacing increased. It decreased by 3.4 and $9.2 \%$ in surface layer and it decrease by 2.8 and $7.8 \%$ in subsurface layer under 30 and $60 \mathrm{~m}$ tile drain spacing, respectively compared to the norrw one.

Soil salinity expressed as electrical conductivity $(E C, d S / m)$ in surface and sunsurface layers as affected by tile drain spacing treatments is shown in Fig. (6). In general, it is obvious that soil salinty increased as soil depth increased. Tile drain spacing treatments realized a postive effect on soil salinity. The reduction in soil salinity followed the order of: 15>30>60 m tile drain spacing. The soil salinity reduced by 13.3 and $41.1 \%$ in surface layer and it reduced by 25.7 and $38.85 \%$ in the subsurface layer under 30 and $60 \mathrm{~m}$ tile drain spacing, respectively compared to the norrw one. 


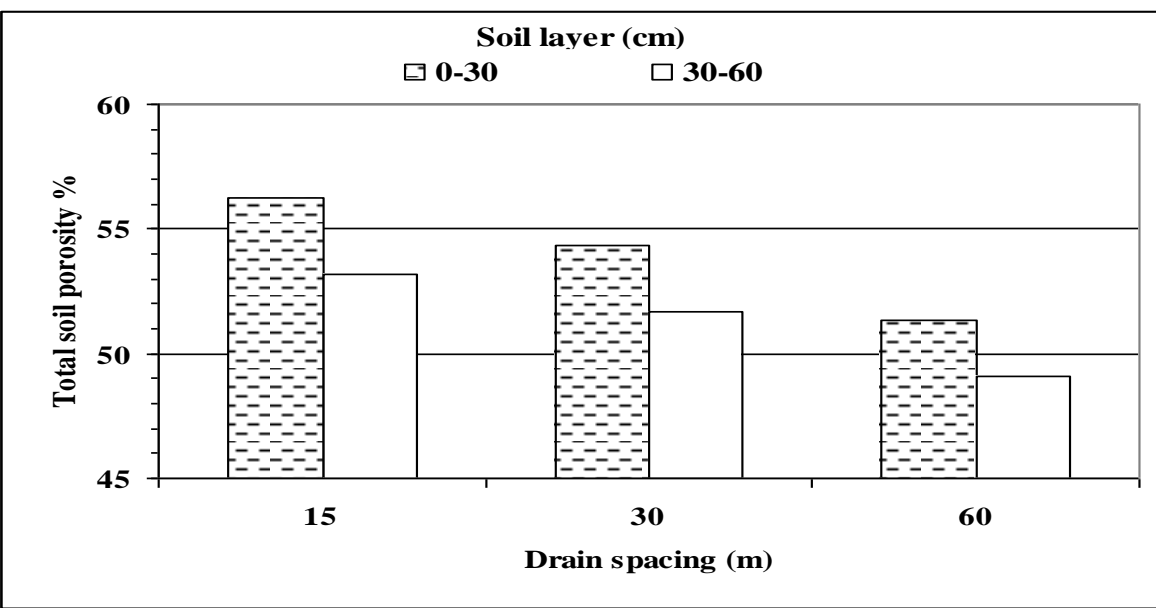

Fig. (5). Total soil porosity (\%) in surface and subsurface layers as affected by tile drain spacing treatments.

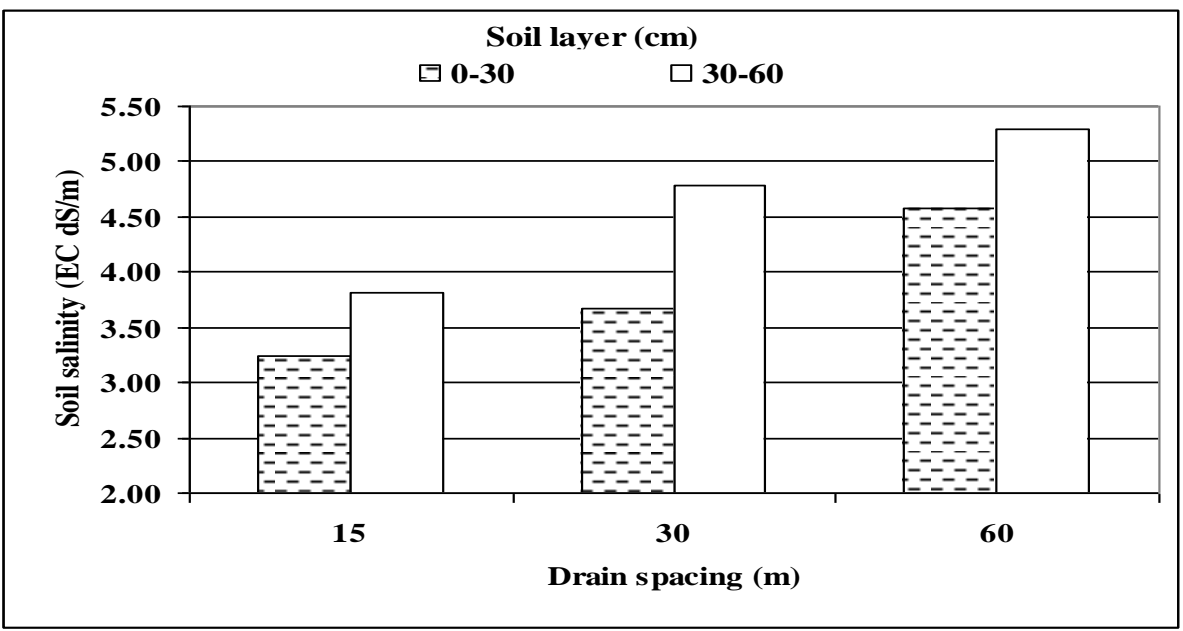

Fig. (6). Soil Salinity $(E C, d S / m)$ in surface and subsurface layers as affected by tile drain spacing treatments.

The sodification phenomenon constitutes highly complicated problems in clayey soils, which hinder its productivity. The obtained data of soil desodification expressed as exchangeable sodium percentage (ESP) as affected by tile drain spacing treatments is shown in Fig. (7). The data revealed that the ESP values increased with soil depth and with wider tile drain spacing. The ESP values under $15 \mathrm{~m}$ tile drain spacing realized a value less than the critical level $(E S P=15)$ of sodicity in both soil layers. The reduction in soil sodicity followed the order of: 15>30>60 m tile drain spacing. The soil sodicity reduced by 13.2 and $45.8 \%$ in surface layer and it reduced by 23.9 and $46.5 \%$ in the subsurface layer under 30 and $60 \mathrm{~m}$ tile drain spacing, respectively compared to the norrw one. 


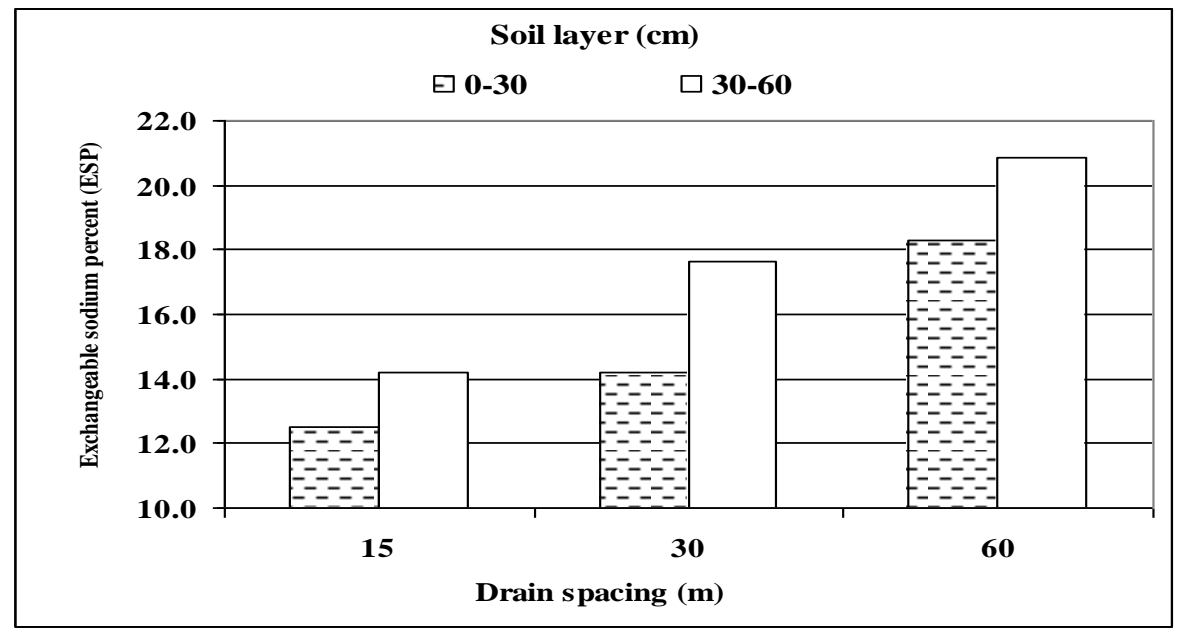

Fig. (7). Soil sodicty (ESP) in surface and subsurface layers as affected by tile drain spacing treatments.

It could be concluded that tile drain spacing treatments realized an enhancing effect by lowering the water table and accelerated its recession, particularly under narrow spacing traetment. In general, it was also, noticed that an improvement in drainage conditions was realized progressively as time proceeds, especially in the treatment of $15 \mathrm{~m}$ tile drain spacing. However, it is worthy to mention that treatment of wider drain spacing $(30 \mathrm{~m})$ gives satisfactory results in lowering watertable and reducing salinity and alkalinity with improving soil physical properties. It is also reduce drainage costs. Also, tile drainage spacing treatments encouraged the existing of a favourable conditions by decreasing soil salinity and sodicity and creating a suitable soil moisture content which plays an important role in improving soil moisture-aeration status in the root zone.

\section{REFERENCES}

Abd-Allah, S.A. (2000). Pedological features studies of some vertisols and aridisols in Egypt. Ph. D. Thesis, Soil Sci. Dept., Fac. of Agric., Ain Shams Univ., Egypt

Dielman, P.J. and Trafford, B.D. (1976). Drainage testing. Irrigation and drainage paper 28, FAO, Rome, $172 \mathrm{p}$.

El-Hadidy, E.M., M.Y.S. El-Arquan, M.A.B. El-Shewikh and M.M. Moukhtar (2003). Drainage in salty clay soil. J. Agric. Sci., Mansoura Univ., special issue, Scientific Symp. On "Problems of soils and water in Dakahlia and Damietta Governorates". March 18, 2003.

Faltas, R.I. and B.H. Naguib (2001). Monitoring of soil salinity and alkalinity changes under different drain spacing and their effects on the redistribution of soil pores and aggregates. Egypt. J. of Appl. Sci., 16 (12): 719-733. 
Houghoudt, S. B.(1940). Oijdrage tot dekenis van engine natuurkudige grootheden van de grond. versal. landb Onderj. No. 46: pp. 515-707.

Klute, A. (1986). "Methods of soil analysis. Part I number 9 in series Agronomy USA.

Mohamedin, A.A.M and N.A. El-Sawaf (2005). Drainage effectiveness to improve environmental conditions in a probelamtic soil of Fayoum. J. of Botany. Fac. of Agric., Assiut Univ., ISSN 1110-0958 Vol. 34 (2).

Moukhtar, M. M., M. H. El-Hakim, M. K. H. Moustafa and A. S. AbdelMawgoud (1990a). Soil conditions and adequate water table depth in Northeastern Delta. Symp. Land Drainage for Salinity Control in Arid and Semi-Arid Regions.2: 102-112. Cairo, Egypt.

Moukhtar, M. M., M. K. H. Moustafa; S.A. Abdel Mawgoud and M. I. Ismail (1990b), 'Field testing for water table control in coastal north east Delta', Egypt. J. Appl. Sc. 5:132-139.

Moukhtar, M. M.; El-Hakim, A.S.A.Abdel-Mawgoud and M.B.El-Shewkih (1996). Open drainage and moling for desalinization of fluvo-marine clay soils of northeastern Egypt. ICID, Cairo, Egypt.

Moukhtar, M. M.; El-Hakim, M. H.; Abdel-Mawgoud, A and Ismail, M. I. (1995). Field experiment for restoring the productivity of a salty clay soil with saline groundwater. International Symposium on Salt-Affected Lagoon Ecosystem, 18- 25/9/1995, Valancia, Spain.

Moukhtar, M.M., M.H. El-Hakim (2004). Drainage, moling and subsoiling in heavy clay soil under saline watertable, Egypt. First African Regional Conference on Drainage (ARCOD): challenges and opportunities for enhancing quality of life. December 6-9, 2004, Cairo, Egypt

Page, A.I., R.H. Miller and D.R. Keeney (1982). "Methods of soil analysis". Part 2: Chemical and microbiological properties, $2^{\text {nd }}$ ed Amer. Soc. Of Agron., Madison, Wisconson, USA.

Ragab, M.A.M. (2000). The effect of calcium carbonate content and size distributions on soil properties, drainage efficiency and crop yield under different designs of tile drainage system. Ph. D. Thesis, Soil Sci. Dept., Fac. of Agric., Ain Shams Univ., Egypt

Rao, K.V.G.K.; S.K. Kamra; P.S. Kumbhar and R.J. Oesterbann (1995). Drainage requirements of alluvial soils of Haryama. Reclamation and management of waterlogged saline soils. National Siminar Proc., 5-8 April, 36-49.

Ritzema, H. P. (1994). Drainage principles and application. ILRI Publication 16, second edition., Wageningen, The Netherlands.

Smedema, L. K. and d. W. Rycroft (1983). "Land Drainage- Planning Design of Agricultural Drainage System". Bastford Acd. And Educ. LTD, London.

Wasef, M. Z. (2004). Studies on tile drainage in some Egyptian soils. Ph. D. Thesis, Fac. of Agric., Moushtoher, Zagazig Univ.

Wenberg, D.R. (1990). Drainage for salinity management. Symp. Land Drainage for Salinity Control in Arid and Semi-Arid Regions.2: 102112. Cairo, Egypt. 
Abdel-Mawgoud, A. S. A. et al.

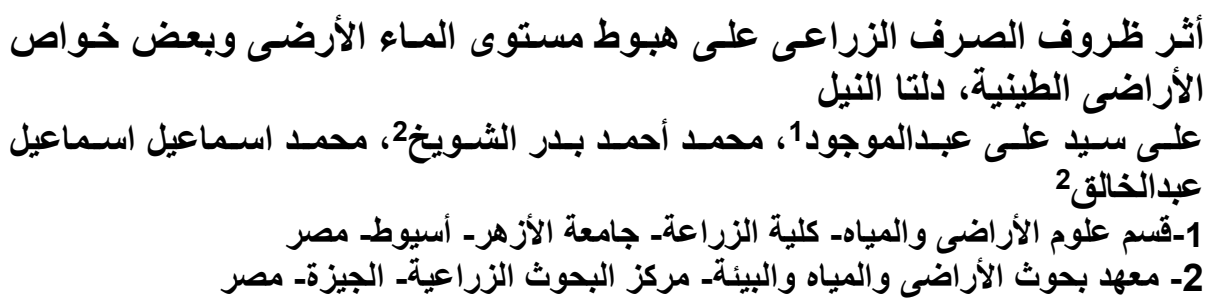

أقفيت تجربة حقلية فى أراضى طينية ثقيلة بشمال الدلتا (محافظة الدقطلية) لدراسة تأثير اختلاف

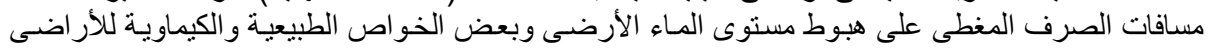

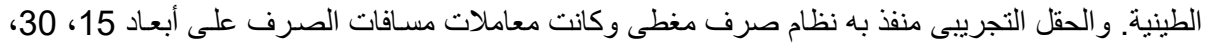

60 مثر وبعمق ثابت 1.5م.

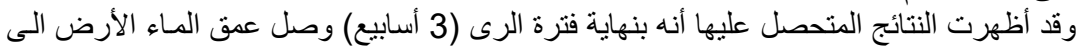

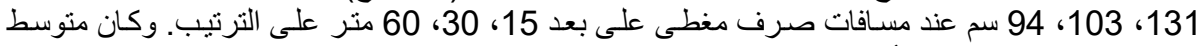

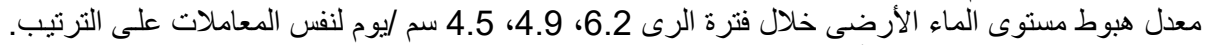

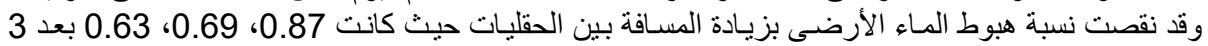

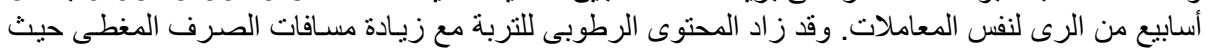

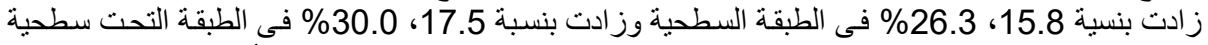

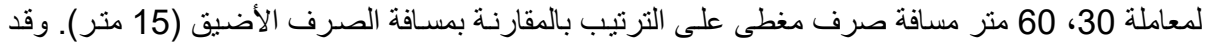

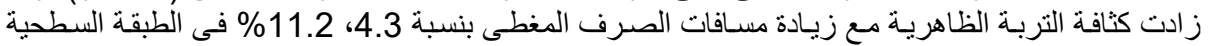

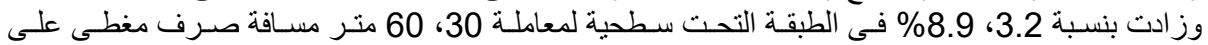

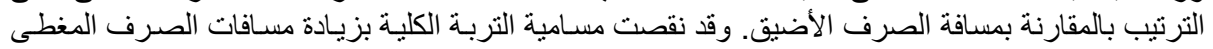

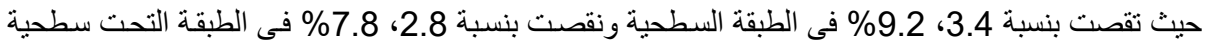

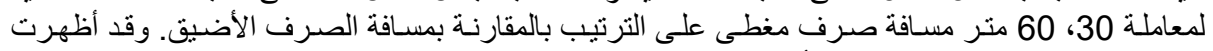

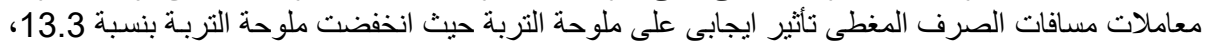

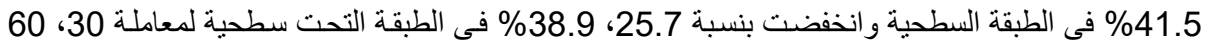

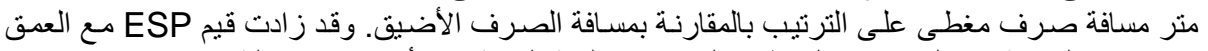

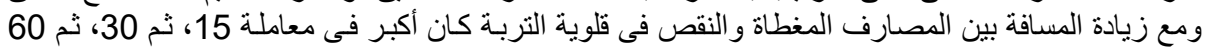

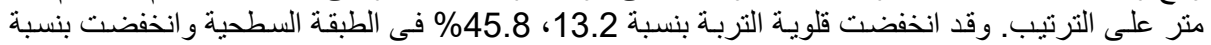
23.9، 46.5\% فى الطبقة النحت سطحية لمعاملة 30، 60 متر مسافة صرف مغطى على على الترتيب بالمقارنة بمسافة الصرف الأضيق.

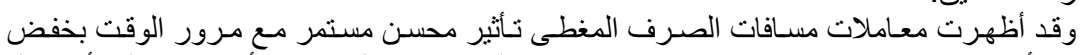

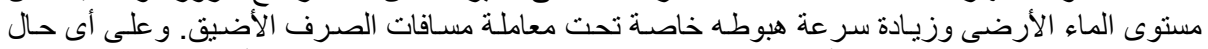

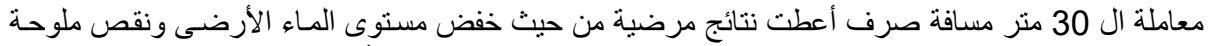

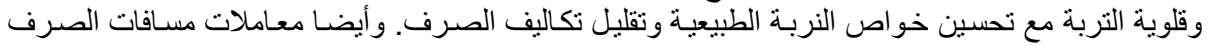

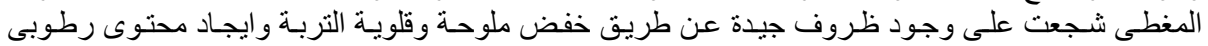
مناسب والذى يلعب دور مهم فى حالات الرطوبة والتهوية فى منطقة الجذور. 
J. Agric. Sci. Mansoura Univ., 32 (1), January, 2007

$\begin{array}{llllllllll}737 & 738 & 739 & 740 & 741 & 742 & 743 & 744 & 745 & 746\end{array}$

$\begin{array}{llllllllll}737 & 738 & 739 & 740 & 741 & 742 & 743 & 744 & 745 & 746\end{array}$ 